\title{
STRATEGI SKIMMING DALAM MENINGKATKAN EFEKTIVITAS BACA SISWA PADA KELAS XI SMK NURUL JADID PAITON PROBOLINGGO \\ Insiyah
}

\author{
Mahasiswi Pascasarjana Universitas Nurul Jadid
}

\begin{abstract}
The objective of this research is to find out the effectiveness of Skimming-Scanning Strategy in improving students reading comprehension. It covered students' literal, inferential, critical comprehension in three types of text. They were narrative, descriptive, and news item texts. The research applied quasi experimental design. The subject of the research was the second grade students of SMK Nurul Jadid Paiton Probolinggo. The data collected were the students' reading achievement through test (pretest and posttest). This research was divided into two groups, experimental and control group, the groups consisted of 28 and 27 students, respectively. The result of the data analysis showed that t-test was higher than t-table $(6.373>2.000)$ or Pvalue (Sig.) was smaller than alpha $(0.000<$ $0.05)$. It meant that mean score of the experimental group was higher than the control group.
\end{abstract}

KEY WORDS: skimming-scanning, reading comprehension levels, three type texts.

\section{A. PENDAHULUAN}

Membaca adalah salah satu dari empat kemampuan bahasa yang diperlukan bagi mereka yang belajar bahasa Inggris sebagai bahasa kedua atau bahasa asing (ESL / EFL). Membaca memegang aturan penting karena membaca adalah salah satu aktivitas yang tidak bisa dilepaskan dalam kehidupan kita untuk mencari informasi atau pengetahuan dari buku teks, artikel, atau majalah yang ditulis dalam bahasa Inggris.(Mundiri, 2017) Dengan demikian, siswa harus memiliki kemampuan membaca yang baik untuk membantu mereka dalam studi akademis. Memahami teks adalah salah satu masalah yang dihadapi siswa dalam membaca. Mereka tidak bisa fokus pada apa yang mereka baca selama kegiatan membaca dan masih memiliki kesulitan untuk mendapatkan ide teks. (Mundiri, 2012) Menjawab tes pemahaman bacaan akan memakan waktu jika mereka menggunakan strategi yang tidak sesuai. Masalah lainnya adalah tidak semua detail informasi dalam bagian ini diperlukan untuk menjawab pertanyaan bacaan namun siswa biasanya membaca bagian bacaan kata demi kata. Membaca kata demi kata juga membuat mereka cepat melupakan apa yang telah mereka baca. Berdasarkan wawancara informal dengan guru Bahasa Inggris di SMK Nurul Jadid Paiton 
Probolinggo, 7 Juli 2017, siswa memiliki keterampilan rendah dalam memahami teks bahasa Inggris dan memiliki partisipasi yang rendah dalam proses belajar mengajar karena mereka sulit untuk memahami dan menangkap informasi dalam membaca. teks, ketika siswa melakukan latihan dalam teks; mereka kesulitan menjawab pertanyaan karena mereka tidak tahu isi teksnya. Selain alasan itu, hal lain yang membuat penulis tertarik untuk melakukan penelitian ini adalah temuan penelitian penelitian kualitatif yang ditemukan oleh Tamsi et al. (2013) yang menunjukkan bahwa guru tidak sepenuhnya berhasil dalam menerapkan strategi skimming dan scanning dalam mengajarkan teks naratif membaca. Hal itu terjadi karena masih ada beberapa langkah yang diajukan oleh Anne Arundel di Lab Studi dan Keterampilan Membaca (1999) yang tidak diterapkan oleh guru. Mengacu pada permasalahan yang ditemukan dan temuan penelitian sebelumnya terkait dengan pemahaman bacaan, penelitian ini akan menetapkan bagaimana efektivitas strategi skimming dan scanning dalam membaca kelas dengan menerapkan semua langkah yang diajukan oleh Anne Arundel (1999). Skimming-scanning adalah strategi dalam mengajarkan pemahaman bacaan. Strategi pemindaian skimming diperlukan untuk membantu siswa memahami teks, mendapatkan informasi terperinci dan tugas membaca lainnya.

\section{Review}

Penelitian tentang penggunaan Peer Editing dalam proses belajar mengajar telah dilakukan oleh beberapa peneliti. Namun, mereka melakukan penelitian dengan berbagai sudut pandang dan metode yang berbeda. Hamra dan Syatriana (2010) dalam artikel mereka yang berjudul "Mengembangkan Model Pengajaran Membaca Pemahaman untuk Siswa EFL" menyatakan bahwa membaca adalah keterampilan yang membutuhkan latihan. Latihan harus mempertimbangkan pengetahuan membaca, pengetahuan sebelumnya, strategi membaca, dan partisipasi membaca. Proses belajar mengajar harus dirancang sedemikian rupa untuk meningkatkan motivasi membaca dan minat siswa. Mereka juga menyarankan model alternatif yaitu The Interactive Model Teaching Reading Comprehension (IMTRC) untuk 
meningkatkan pemahaman bacaan siswa EFL. Alternatif lain yang mereka ajukan adalah Model Teaching Reading (Hamra dan Syatriana, 2012). Penelitian lain yang terkait dilakukan oleh Iravani dan Atghia-ee (2013), dari Universitas Payam-e-noor, Iran. Penelitian ini membahas tentang efek skimming dan pemindaian via $\mathrm{CD}$ multimedia pada pemahaman bacaan. Pendekatan kuasi eksperimental digunakan dalam penelitian ini. Temuan menunjukkan bahwa siswa di kelompok eksperimen tampil lebih baik (29,5\%) dibanding kelompok kontrol. Dapat disimpulkan bahwa walaupun metode pengajaran tradisional yang digunakan untuk kemampuan membaca dapat memberi dampak positif kepada siswa, penggunaan pendekatan inovatif (yaitu pembelajaran bahasa dibantu komputer) dapat memberikan hasil yang lebih baik. Tamsi dkk. (2013) juga melakukan penelitian kualitatif berjudul "Implementasi Strategi Skimming dan Scanning dalam Mengajarkan Teks Narasi Membaca kepada Siswa Kelas I SMAN 21 Surabaya". Hasil penelitian ini menunjukkan bahwa guru tidak sepenuhnya berhasil dalam menerapkan strategi skimming dan scanning dalam pengajaran teks naratif membaca. Alasannya karena masih ada beberapa langkah yang tidak diaplikasikan oleh guru. Sedangkan berdasarkan kuesioner yang telah dijawab oleh para siswa, dapat dilihat bahwa respon siswa terhadap strategi skimming dan scanning itu baik. Abdelrahman dan Bsharahin (2014) dalam artikel mereka, "Pengaruh Strategi Membaca Kecepatan untuk Mengembangkan Pemahaman Membaca di antara Siswa Sekunder Kedua dalam Bahasa Inggris" menemukan hasil penelitian ini menunjukkan bahwa ada perbedaan yang signifikan pada pemahaman bacaan karena kecepatan membaca. strategi melalui skimming dan scanning yang menunjukkan bahwa pelatihan efektif untuk kelompok eksperimen. Prosedur pelatihan dan kegiatan instruksional meningkatkan kinerja siswa dalam skala pemahaman baca. Skimming-scanning adalah strategi dalam mengajarkan pemahaman bacaan. Harmer (2001: 202) menyatakan bahwa skimming adalah teknik dalam mencari teks untuk mendapatkan gambaran singkat tentang inti sebuah teks. Sementara, strategi pemindaian adalah strategi untuk menemukan informasi spesifik dengan cepat dalam teks 
sambil mengabaikan makna yang lebih luas (Brown, 2001). Kedua strategi tersebut membantu siswa untuk membaca secara lebih fokus dan efisien. Oleh karena itu, strategi pemindaian skimming mempercepat strategi membaca dengan cepat mencari ide dan informasi spesifik teks. Skimming-scanning adalah strategi membaca cepat. Strategi ini bertujuan untuk mendapatkan ide dan informasi spesifik teks dengan cepat. Menurut Brown (2004: 213) skimming adalah proses liputan materi bacaan yang cepat untuk menentukan inti atau gagasan utamanya. Selain itu, Maxwell (1970) menyatakan bahwa pemindaian adalah kemampuan untuk menemukan fakta dan rincian spesifik dengan cepat. Pemindaian skimming dianggap sebagai keterampilan membaca yang diinginkan dan diajarkan dalam kebanyakan kursus membaca perkembangan karena membantu siswa mendapatkan informasi dengan mudah dengan cara yang efisien. Menurut Arundel di Reading and Study Skill Lab (1999), skimming adalah strategi untuk mengalihkan mata dengan cepat dari teks dengan tujuan untuk mendapatkan hanya gagasan utama dan gambaran umum dari konten. Selanjutnya, ada beberapa langkah diDengan menerapkan strategi skimming, yaitu: (1) Baca judulnya, (2) Baca pengantar paragraf utama, (3) Baca paragraf pertama sepenuhnya, jika ada subpos, baca masing-masing, cari hubungan di antara mereka, (4 ) Baca kalimat pertama dari setiap paragraf yang tersisa, (5) Bacalah teks untuk mencari kata-kata petunjuk, kata benda yang benar, kata-kata yang tidak biasa, penghitungan, kata sifat kualifikasi, isyarat tipografis, (6) Bacalah paragraf terakhir sepenuhnya. Dia juga mempresentasikan beberapa langkah untuk memaksimalkan penggunaan sistem pemindaian pada pemahaman bacaan: (1) Ingatlah setiap saat apa yang Anda cari, (2) Antisipasi dalam bentuk apa informasi tersebut kemungkinan akan muncul nomor, kata benda yang tepat, dll (3) Menganalisis pengorganisasian konten sebelum mulai memindai. Jika bahannya sudah familiar atau cukup singkat, kami mungkin bisa memindai keseluruhan artikel dalam satu pencarian. Tetapi jika bahannya panjang atau sulit, mungkin perlu untuk menentukan bagian mana dari artikel yang akan dipindai. (4) Biarkan mata Anda berjalan cepat melewati beberapa garis cetak setiap kali, (5) Baca 
keseluruhan kalimat saat Anda menemukan kalimat yang memiliki informasi yang Anda cari. Berdasarkan informasi di atas, dapat disimpulkan bahwa strategi skimming dan scanning dapat digunakan oleh siswa untuk memahami teks naratif '

\section{Tujuan penelitian}

Tujuan dari penelitian ini adalah untuk mengetahui efektivitas strategi pemindaian skimming dalam pengajaran membaca untuk meningkatkan pemahaman bacaan siswa.

\section{B. METODOLOGI}

Penelitian ini menggunakan kuasi eksperimen dengan rancangan kelompok non equivalent yang melibatkan dua kelompok. Mereka adalah kelompok eksperimen dan kontrol. Kedua kelompok mewakili kelompok eksperimen dan kontrol dari dua kompetensi keterampilan, masing-masing adalah kelompok Teknik Komputer Jaringan (TKJ) dan Kelompok Multimedia (MM). Kelompok TKJ terdiri dari 28 siswa dan kelompok MM terdiri dari 27 siswa. Instrumen yang digunakan dalam penelitian ini adalah tes membaca. Tes pemahaman bacaan ditujukan untuk mengukur pemahaman bacaan siswa dalam teks naratif, deskriptif, dan berita tentang penggunaan strategi pemindaian skimming. Model uji bacaan adalah tes objektif dalam tes pilihan ganda. Sebelum memberikan pengobatan, peneliti memberikan tes baca sebagai pre-test untuk kelompok eksperimen dan kontrol. Tujuan dari tes ini adalah untuk mengenali keduanyatingkat kelompok sebelum memulai program eksperi men dan untuk membandingkan hasil pre-test dengan hasil post-test setelah intervensi.

\section{Analisis dan hasil data}

\section{a. Peningkatan pemahaman bacaan siswa}

T-test sampel independen dilakukan untuk menentukan apakah kelompok eksperimen dinilai secara signifikan lebih tinggi daripada kelompok kontrol dengan nilai rata-rata tes pemahaman sebelum dan sesudah membaca. 
Tabel 1. Hasil Uji Pre test dan Post test siswa

\begin{tabular}{|l|l|c|l|l|l|l|}
\hline & Group & $\mathbf{N}$ & \multicolumn{1}{|c|}{ Mean } & \multicolumn{1}{|c|}{ S.D } & Sig. (2 tailed) & Gain \\
\hline Pretest & Ekperimen & 28 & 54,6 & 9,04 & 0,929 & \\
& Control & 27 & 54,41 & 8,77 & & \\
\hline Postest & Ekperimen & 28 & 71,98 & 6,92 & 0,000 & 17,38 \\
& Control & 27 & 58,22 & 7,12 & & 3,81 \\
\hline
\end{tabular}

Berdasarkan tabel 1, terlihat bahwa jumlah siswa adalah 53 siswa yang terdiri dari 28 siswa pada kelompok eksperimen dan 27 siswa pada kelompok kontrol. Perbandingan nilai rata-rata tes pemahaman pra dan pasca membaca menunjukkan kenaikan sebesar 17,38 untuk kelompok eksperimen, dan kenaikan 3,81 untuk kelompok kontrol. Hipotesis diuji dengan menggunakan analisis inferensial. Dalam hal ini, peneliti menggunakan uji t (test of significance) atau Independent-Sample ttest untuk mengetahui perbedaan yang signifikan antara hasil skor rata-rata skor dua kelompok (kelompok eksperimen dan kontrol). Hasil uji-t dapat dilihat pada tabel berikut:

Tabel 2. Analisis t-test

\begin{tabular}{|l|l|l|l|l|}
\hline Variabel & t-test & Df & t-table & Sig. (2 tiled) \\
\hline Postest & 6.373 & 53 & 2.000 & 0.000 \\
\hline
\end{tabular}

Tabel 2 menunjukkan adanya perbedaan yang signifikan antara t-table dan t test. Uji t lebih tinggi dari $\mathrm{t}$ tabel atau 6,373> 2.000. Itu berarti setelah treatment, pemahaman bacaan siswa meningkat.

\section{b. Peningkatan siswa terhadap tiga tingkat pemahaman bacaan}


Tabel 3. Skor Pre test, Post test dan Standar Deviasi Pemahaman Membaca Tiga

Tingkat Siswa

\begin{tabular}{|c|c|c|c|c|c|c|c|}
\hline & \multirow[t]{2}{*}{ Group } & \multicolumn{2}{|c|}{$\begin{array}{l}\text { Pemahaman } \\
\text { Literal }\end{array}$} & \multicolumn{2}{|c|}{$\begin{array}{l}\text { Pemahaman } \\
\text { Inferensial }\end{array}$} & \multicolumn{2}{|c|}{ Pemahaman Kritis } \\
\hline & & Mean & SD & Mean & SD & Mean & SD \\
\hline Pretest & $\begin{array}{l}\text { Ekperimen } \\
\text { Kontrol }\end{array}$ & $\begin{array}{l}75,35 \\
76,29\end{array}$ & $\begin{array}{l}17,10 \\
16,20\end{array}$ & $\begin{array}{l}50,35 \\
50,55\end{array}$ & $\begin{array}{l}18,15 \\
18,60\end{array}$ & $\begin{array}{l}38,21 \\
37,03\end{array}$ & $\begin{array}{l}16,34 \\
11,37\end{array}$ \\
\hline Postest & $\begin{array}{l}\text { Ekperimen } \\
\text { Kontrol }\end{array}$ & $\begin{array}{l}78,57 \\
75,55\end{array}$ & $\begin{array}{l}12,97 \\
14,23\end{array}$ & $\begin{array}{l}75,00 \\
58,14\end{array}$ & $\begin{array}{r}13,74 \\
12,10\end{array}$ & $\begin{array}{l}62,50 \\
40,37\end{array}$ & $\begin{array}{l}15,54 \\
10,55\end{array}$ \\
\hline
\end{tabular}

Tabel 3 menunjukkan bahwa tidak ada perbedaan yang signifikan antara skor rata-rata siswa dan standar deviasi dalam tiga tingkat pemahaman bacaan kedua kelompok dalam pretest. Setelah mendapatkan perawatan, kedua kelompok mengalami peningkatan dalam tingkat pemahaman membaca dan inferensial. Hanya tingkat literal yang menurun pada kelompok kontrol. Dalam hal ini, peneliti menggunakan paired ttest untuk mengetahui perbedaan yang signifikan antara tingkat pemahaman siswa terhadap skor pretest dan posttest pada kedua kelompok (kelompok eksperimen dan kelompok kontrol). Hasil uji paired ttest dapat dilihat sebagai berikut:

Tabel 4. Analisis Uji Coba Paired Kelompok Eksperimental

\begin{tabular}{|l|l|l|l|l|}
\hline Variable & t-test & Df & t-table & Sig. (2 tiled) \\
\hline Literal & 1,071 & 27 & 2,052 & 0,294 \\
Inferential & 5,921 & 27 & 2,052 & 0,000 \\
Critical & 8,422 & 27 & 2,052 & 0,000 \\
\hline
\end{tabular}


Tabel 4. menunjukkan ada perbedaan yang signifikan antara t-tabel dan ttest pada tingkat inferensial dan kritis setelah perlakuan dengan menggunakan strategi Skimming-Scanning. Pernyataan tersebut dibuktikan dengan nilai t-test dari pemahaman inferensial $(5,921)$ dan pemahaman kritis $(8,422)$ yang lebih tinggi dari nilai t tabel $(2,052)$, pada tingkat signifikansi 0,05 dan tingkat kebebasan $(\mathrm{N}-1)=(28$ $1)=27$, atau sig. (2-tailed) lebih kecil dari $\alpha(0,000<0,05, \mathrm{df}=27)$. Namun, tidak ada perbedaan yang signifikan antara t-tabel dan t-test dalam pemahaman literer dimana nilai uji-tlebih kecil dari t tabel $(1,071<2,052)$ atau sig (2-tailed) lebih tinggi dari $\alpha$ $(0,294>0,05, \mathrm{df}=27)$.

Tabel 5. Analisis Uji T-pair Paired Control Group

\begin{tabular}{|l|l|l|l|l|}
\hline Variable & t-test & Df & t-table & Sig. (2 tiled) \\
\hline Literal & $-0,217$ & 26 & 2,056 & 0,830 \\
Cnferential & 2,137 & 26 & 2,056 & 0,042 \\
& 1,275 & 26 & 2,056 & 0,214 \\
\hline
\end{tabular}

Tabel 5 menunjukkan adanya perbedaan yang signifikan antara t tabel dan ttest pada tingkat inferensial setelah perlakuan dengan menggunakan strategi Direct Reading-Thinking Activity (DRTA). Pernyataan tersebut dibuktikan dengan nilai t-test dari inferensial inferensial (2.135) yang lebih tinggi dari nilai t tabel $(2,056)$, pada tingkat signifikansi 0,05 dan derajat kebebasan $(\mathrm{N}-1)=(27-1)=26$, atau sig $(2-$ tailed) lebih kecil dari $\alpha(0,000<0,05, \mathrm{df}=26)$. Namun, tidak ada perbedaan yang signifikan antara t tabel dan t-test secara literal dan kritis dimana nilai t-test lebih kecil 
dari t tabel, $(-0,217<2,056)$ dan $(1,275<2,056)$, atau sig. ekor) lebih tinggi dari $\alpha$ $(0,830>0,05, \mathrm{df}=26)$ dan $(0,214>0,05, \mathrm{df}=26)$.

c. Peningkatan tiga jenis teks pemahaman bacaan siswa

Tabel 6. Skor Nilai Pretest, Postest dan Standar Deviasi Tiga jenis teks

\begin{tabular}{|c|c|c|c|c|c|c|c|}
\hline \multirow{2}{*}{\multicolumn{2}{|c|}{ Group }} & \multicolumn{2}{|c|}{$\begin{array}{l}\text { Narrative } \\
\text { (N) }\end{array}$} & \multicolumn{2}{|c|}{$\begin{array}{l}\text { Discriptive } \\
\text { (D) }\end{array}$} & \multicolumn{2}{|c|}{$\begin{array}{l}\text { News Item } \\
\text { (NI) }\end{array}$} \\
\hline & & Mean & SD & Mean & SD & Mean & SD \\
\hline Pretest & $\begin{array}{l}\text { Ekperimen } \\
\text { Kontrol }\end{array}$ & $\begin{array}{l}56,78 \\
55,18\end{array}$ & $\begin{array}{l}15,88 \\
12,51\end{array}$ & $\begin{array}{l}52,50 \\
53,70\end{array}$ & $\begin{array}{l}17,76 \\
17,79\end{array}$ & $\begin{array}{l}54,75 \\
54,44\end{array}$ & $\begin{array}{l}16,39 \\
16,25\end{array}$ \\
\hline Postest & $\begin{array}{l}\text { Ekperimen } \\
\text { Kontrol }\end{array}$ & $\begin{array}{l}72,50 \\
62,96\end{array}$ & $\begin{array}{l}12,94 \\
14,88\end{array}$ & $\begin{array}{l}73,21 \\
54,81\end{array}$ & $\begin{array}{l}12,18 \\
13,69\end{array}$ & $\begin{array}{l}69,28 \\
56,29\end{array}$ & $\begin{array}{l}14,12 \\
13,05\end{array}$ \\
\hline
\end{tabular}

Tabel 6 menunjukkan nilai rata-rata siswa dan standar deviasi dalam tiga jenis pemahaman bacaan yang peneliti gunakan dalam penelitian ini. Data menunjukkan bahwa tidak ada perbedaan yang signifikan antara skor rata-rata siswa dan standar deviasi dalam tiga jenis teks dari pemahaman bacaan kedua kelompok dalam pretest Setelah mendapat perawatan, kedua kelompok mengalami peningkatan dalam narasi, deskriptif, dan teks berita tentang pemahaman bacaan. Peneliti menggunakan paired t-test untuk mengetahui perbedaan yang signifikan antara pemahaman bacaan siswa dengan skor rata-rata tiga jenis teks dalam pretest dan posttest untuk kedua kelompok (kelompok eksperimen dan kelompok kontrol). Hasil uji paired t test dapat dilihat sebagai berikut: 


\begin{tabular}{|l|l|l|l|l|}
\hline Variable & t-test & Df & t-table & Sig. (2 tiled) \\
\hline Narrative & 5,943 & 27 & 2,052 & 0,000 \\
Descriptive & 4,923 & 27 & 2,052 & 0,000 \\
News Item text & 5,079 & 27 & 2,052 & 0,000 \\
\hline
\end{tabular}

Tabel 7 menunjukkan ada perbedaan yang signifikan antara t tabel dan ttest pada narasi, deskriptif, dan teks item berita setelah perawatan dengan menggunakan strategi SkimmingScanning. Pernyataan tersebut dibuktikan dengan nilai t-test teks naratif (5.943), teks deskriptif (4.923), dan teks item berita (5.079) yang lebih tinggi dari nilai t tabel (2.052), pada tingkat signifikansi 0,05 dan derajat kebebasan $(\mathrm{N}-1)=$ $(28-1)=27$, atau sig. (2-tailed) lebih kecil dari $\alpha(0,000<0,05, \mathrm{df}=27)$.

Tabel 8. Analisis Uji-T berpasangan Kelompok Kontrol

\begin{tabular}{|l|l|l|l|l|}
\hline Variable & t-test & Df & t-table & Sig. (2 tiled) \\
\hline Narrative & 2,840 & 26 & 2,056 & 0,009 \\
Descriptive & 0,372 & 26 & 2,056 & 0,713 \\
News Item text & 0,756 & 26 & 2,056 & 0,456 \\
\hline
\end{tabular}

Tabel 8 menunjukkan adanya perbedaan yang signifikan antara t-tabel dan ttest pada teks naratif setelah perlakuan dengan menggunakan strategi Direct ReadingThinking Activity (DRTA). Pernyataan tersebut dibuktikan dengan nilai t-test teks naratif (2.480) yang lebih tinggi dari nilai t tabel (2.056), pada tingkat signifikansi 0,05 dan tingkat kebebasan $(\mathrm{N}-1)=(27-1)=26$, atau sig (2-tailed) lebih kecil dari $\alpha$ $(0,000<0,05, \mathrm{df}=26)$. Namun, tidak ada perbedaan yang signifikan antara t tabel dan t-test pada teks deskriptif dan teks item dimana nilai t-test lebih kecil dari ttabel, 
$(0,372<2,056)$ dan $(0,756<2,056)$, atau sig. $(2$-tailed $)$ lebih tinggi dari $\alpha(0,830>$ $0,05, \mathrm{df}=26)$ dan $(0,214>0,05, \mathrm{df}=26)$.

\section{DISKUSI}

Secara keseluruhan, temuan menunjukkan bahwa siswa kelompok eksperimen meningkatkan pemahaman bacaan mereka setelah perawatan dengan menggunakan strategi pemindaian skimming. Selama proses perawatan, peneliti memusatkan perhatian pada peningkatan kemampuan membaca melalui strategi pemindaian skimming, siswa juga melakukan berbagai aktivitas tentang apa yang mereka baca seperti menjawab pertanyaan atau menggarisbawahi verba. Para siswa di SMK Nurul Jadid tidak terbiasa menggunakan strategi pemindaian skimming, oleh karena itu ketika harus melakukan latihan membaca mereka mengalami kesulitan karena mereka tidak mengerti teksnya. Para siswa berpikir bahwa untuk memahami teks yang mereka butuhkan untuk mengetahui arti setiap kata. Setelah melakukan strategi skimmingscanning, para siswa menyadari bahwa mereka tidak perlu mengetahui arti semua kata dalam teks untuk mendapatkan ide utama. Diaz dan Laguado (2013) dalam penelitian tindakan mereka menemukan bahwa strategi pemindaian skimming membantu siswa mengubah kepercayaan dan persepsi mereka tentang membaca dan mengubah praktik membaca mereka menjadi lebih baik. Perubahan kebiasaan siswa membaca kata demi kata ke skim-memindai bagian tersebut untuk menjawab pertanyaan bacaan membantu siswa dalam pemahaman bacaan mereka yang cepat. Pada pretest, sebagian besar siswa yang berada dalam kelompok kontrol dan eksperimen tidak menjawab beberapa pertanyaan dan mengeluhkan waktu yang terbatas (30 menit) yang peneliti berikan. Tapi, setelah perawatan, beberapa siswa dalam kelompok eksperimen menyelesaikan posttest mereka sebelum waktu yang terbatas. Mereka hanya membaca dan menjawab pertanyaan secepat mungkin. Menurut Brown (2004: 213) skimming adalah proses 
liputan materi bacaan yang cepat untuk menentukan inti atau gagasan utamanya. Sebagai tambahan, Maxwell (1970) mendefinisikan pemindaian sebagai kemampuan untuk menemukan fakta dan rincian spesifik dengan cepat sehingga dianggap sebagai keterampilan membaca yang diinginkan dan diajarkan dalam kebanyakan kursus membaca perkembangan. Selama perawatan, peneliti memberi siswa waktu yang terbatas dalam beberapa kegiatan. Dia memberi waktu 2 menit kepada para siswa untuk mencari tahu atau menggarisbawahi kata-kata verba di bagian tersebut. Pada pertemuan pertama mereka membaca perikop kata demi kata, bukan untuk skimscan teksnya sehingga mereka lamban untuk menemukan kata-katanya. Peneliti juga memberi waktu terbatas ( 2 atau 3 menit) saat melatih siswa dalam berbagai pilihan. Pada pertemuan kedua, para siswa menjadi lebih baik menggunakan pemindaian skimming untuk menghemat waktu mereka dalam menjawab pertanyaan meskipun kebanyakan dari mereka masih lamban dalam membaca pemahaman, namun pertemuan berikutnya mereka menjadi lebih cepat dan lebih cepat untuk menemukan dan menjawab pertanyaan. Abdelrahman dan Bsharahin (2014) menyatakan bahwa jika peserta didikIngin cepat memahami teks, dia perlu mempraktikkan skimmingscanning. Dalam hal tingkat pemahaman bacaan siswa, sebagian besar siswa mendapat peningkatan dalam pemahaman tingkat inferensial dan kritis pada kelompok eksperimen seperti ditunjukkan pada tabel 4.5. Di tingkat ini, pembaca diminta untuk mendapatkan gagasan yang tersirat, untuk membuat penilaian evaluatif tentang beberapa aspek teks, dan untuk mengintegrasikan proses membaca dan berpikir (Cooper et al, 1979: 29). Hal itu juga terkait dengan Maxwell (1970: 7) menyatakan bahwa skimming awal untuk menemukan poin utama tidak hanya berfungsi untuk membantu pembaca mengatur gagasannya, namun juga meningkatkan kepercayaan dirinya bahwa ia dapat memahami dan mempertahankan informasi tersebut. Tamsi dkk. (2013) melakukan penelitian kualitatif di SMAN 21 Surabaya. Berdasarkan 
kuesioner yang telah dijawab oleh para siswa, dapat dilihat bahwa respon siswa terhadap strategi skimming dan scanning cukup baik. Hasilnya juga menunjukkan bahwa guru tersebut tidak sepenuhnya berhasil dalam menerapkan strategi pemindaian skimming dalam mengajarkan teks naratif membaca. Alasannya karena masih ada beberapa langkah yang tidak diaplikasikan oleh guru. Namun, setelah peneliti melakukan strategi pemindaian skimming di SMK Nurul Jadid Paiton Probolinggo, siswa menunjukkan prestasi yang berbeda dalam posttest mereka dalam teks naratif, deskriptif, dan berita dari pretest pada kelompok eksperimen yang berarti siswa memiliki peningkatan yang baik dalam tiga jenis teks. Berdasarkan hasil penelitian, data menunjukkan bahwa perbedaan pemahaman bacaan siswa setelah perlakuan dipengaruhi oleh perlakuan yang diberikan kepada mereka. Hal itu dibuktikan dengan hasil analisis data statistik yang menunjukkan kemajuan siswa. Oleh karena itu, dapat disimpulkan bahwa ada perbedaan yang signifikan antara pemahaman bacaan siswa sebelum dan sesudah diajarkan dengan menggunakan Skimming-Scanning Strategy.

\section{Daftar Pustaka}

Anderson, R. C., E. H. Hiebert, J. A. Scott, \& I. A. G. Wilkinson. 1985. Becoming a nation of readers: The report of the Commission on Reading. Champaign: Center for the Study of Reading, Univ. of Illinois.

Antoni, Nurman. 2010. Exploring EFL Teachers' Strategies in Teaching Reading Comprehension. Jurnal Penelitian Pendidikan, (Online). Vol. 11, No. 2. (http:// jurnal.upi.edu/file/5-Nurman_Antoni.pdf, accessed on 6th February 2014).

Arikunto, Suharsimi. 2006. Prosedur Penelitian Suatu Pendekatan Praktik. Jakarta: Rineka Cipta. Arundel, Anne. 1999. Reading and Study Skill Lab: Skimming and Scanning.

Article, (Online). (http://www.aacc.edu/tutoring/file/skimming.pdf, accessed on 6th February 2014).

Baratieri, Jacir Paulo. 2013. The Reading Process Models. Article, (Online). (http://baratieri.tripod.com/id24.html, accessed on 6th February 2014). 
Barnett, M. 1988. Teaching through context: How Real and Perceived Strategy Use Affect L2 Comprehension. The Modern Language Journal. Vol. 77, 150-162.

Bedoya, Lia D.S. M. 2013. Improving Reading Comprehension and Self-directed Learning through the Use of Explicit Reading Strategies and Personal Blogs on High School Students. Online Published Thesis. Chia:University

Benešová, Veronika. 2006. Testing Reading in English Language Teaching. Paper, (Online).(http://www.google.com.

Chavangklang, Pitchayapa. 2008. Assessing Reading Strategy Training Using a CallBased Approach forThai EFL Students' English Hyper Text Reading. Online Published Thesis. Thailand: Suranaree University of Technology. (Error! Hyperlink reference not valid., accessed on 6th February 2014).

Cooper, J. D., Warncke, E. W., Ramstad, P. A., \& Shipman, D. A. 1979. The what and how of reading instruction. Columbus:

Charles E. Merrill. Damayanti, Yuanita. 2013. Implementing Skimming to Teach Reading Comprehension. Article, (Online). http://www.academia.edu/1142418/ Implementing_Skimming_to_Teach_Reading_Comprehension, accessed on 6th February 2014).

Diaz, Sindy \& Laguado J. C. 2013. Improving Reading Skills through Skimming and Scanning Techniques at a Public School: Action Research. Open Writing Doors, (Online). Vol. 10, No. 1. (http://revistas.unipamplona.edu.co/ojs_ viceinves/ index.php/OWD/article/view/240/230, accessed on 6th February 2014).

Dorkchandra, Dentisak. 2010. Enhancing English Reading Comprehension through A Text Structure Reading Strategy CALL Program. Online Published Thesis. Thailand: Suranaree University of Technology. (http://sutir.sut.ac.th:8080/ sutir/bitstream/123456789/3708/2/fulltext.pdf, accessed on 6th February 2014)

El-Deen, Zulfa Badr. 2009. The Effectiveness of Assisted Extensive Reading on Developing Reading Comprehension Strategies for Ninth Graders in Gaza Governorate. Online Published Thesis. Gaza: The Islamic University. (http:// library.iugaza.edu.ps/thesis/86895.pdf, Accessed on 6th February 2014)

El_Koumy, AS.AK. 2006. The Effects of the Directed Reading-Thinking Activity on EFL Students' Referential and Inferential Comprehension. (http:// files.eric.ed.gov/fulltext/ED502645.pdf, Accessed on 6th February 2014).

Maxwell , Martha J. 1972. Skimming and Scanning Improvement: The Needs, Assumption and Knowledge Base. Journal of Reading Behavior, (Online). Vol. 5, No. 1, Winter. (http://jlr.sagepub.com/content/5/1/47.full.pdf, accessed on 6th February 2014).

Mikulecky, S. Beatrice \& L. Jeffries. 2004. More Reading Power. New York: Pearson Education Ltd. Munir, Ardi. 2012. Generic Structure and Example News Item Text. Article (Online). (http://smp3lembang.blogspot.com/2012/08/generic-structureandexample-news-item.html, accessed on 6th February 2014)

Munir, Nurasia. 2009. Using Shared Reading Strategy to Improve Reading Comprehension. Unpublished thesis. Makassar: Graduate Program of the State University of Makassar. 
Nga, Nguyen T. T. 2009. Teachers' Beliefs about Teaching Reading Strategies and Their Classroom Practices: A Case Study of Viet Ba High School. Online Published Thesis.Vietnam: Vietnam National University. (http://www.asianefljournal.com/Thesis-N-Nga.pdf, accessed on 6th February 2014)

Nunan, David. (Ed.). 2003. Practical English Language Teaching. New York: McGraw Hill. Nuttal, Christine. 2005. Teaching Reading Skills in a Foreign Language. Oxford: Macmillan.

O'Malley, J. \& Chamot, A. 1990. Learning strategies in second language acquisition. UK: Cambridge University Press.

Pang, E. S., Muaka A, Bernhardt, E. B., \& Kamil, M. L. Teaching Reading. International Academy and BUREAU of Education. Educational Practise Series - 12 (Online). (https://smec.curtin.edu.au/local/docs/prac12e.pdf, accessed on 6th February 2014).

Rahim, Fathur. 2009. Teaching Reading. Jakarta: MGMP Bermutu, (Online). (http://mmursyidpw.files.wordpress.com/2009/05/teachingreading.pdf, accessed on 6th February 2014).

Royer, J. M. \& Cunningham D. J. 1978. The Theory and Measurement of Reading Comprehension. Massachusetts: The National Institute of Education.

Ruga, 2012. Definition Of Recount, Report, Narrative, Descriptive and Procedure Text. Article, (Online). (http://rugayamanan.wordpress.com/2012/ 12/08/definition-ofrecount-report-narrative-descriptive-and-proceduretext/, accessed on 6th February 2014).

Snow, Catherine E. 2002. Reading for Understanding : Toward a Research and Development Program in Reading Comprehension. Santa Monica: RAND Reading Study Group.

Mundiri, A. (2012). PENDIDIKAN TEKNOHUMANISTIK BERBASIS CORE ETHICAL VALUES. At-Tajdid, 1(1), 37-47.

Mundiri, A. (2017). Organizational Culture Base On Total Quality Management In Islamic Educational Institution. ADRI International Journal Of Islamic Studies and Social Sciences, 1(1), 1-11. 